\title{
Structure of Anopheles (Diptera: Culicidae) population in areas with different degrees of human settlement: Cantá - Roraima - Brazil
}

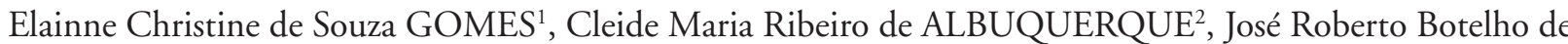 \\ SOUZA $^{2}$, Mércia Eliane ARRUDA ${ }^{3}$, Ulisses Eugênio Cavalcanti CONFALONIERI ${ }^{4}$
}

\begin{abstract}
Malaria has still been one of the most important endemic diseases in the Amazonian region. This study presents the impact of human settlements on the structure of Anopheles population. Diversity, abundance, richness and distribution of the genus Anopheles were observed in two areas with different levels of human settlement in the Cantá city, Roraima State, Northern Brazil. The influence of the dry and rainy seasons on mosquito populations was also observed. Mosquito captures were performed between 6:00 and 10:00 pm during the dry (February and November) and rainy (May and August) seasons at four different sites of each area. Among the 11 species of Anopheles identified through the adults' characteristics, An. albitarsis s.l. (45.5\%) and An. darlingi (19.2\%) were the most abundant in the more intensively anthropized area while An. triannulatus (19.2\%) was more common in the less modified area. Other species found were An. nuneztovari (10.9\%), An. oswaldoi (2.0\%), An. evansae (1.7\%), An. brasiliensis (0.6\%), An. intermedius (0.3\%), An. mediopunctatus (0.5\%), An. periassui (0.08\%) and An. argyritarsis $(0.04 \%)$. The highest mosquitoes' population density was observed in May and the lowest one was observed in February and November. These results demonstrate the existence of a high diversity of anophelines in the study areas, showing that anthropic changes in the environment and climate variability affect both the population density and relative abundance of these vectors.
\end{abstract}

KEYWORDS: Anophelines, Anthropized, Anopheles ecology, Climate variability, Malaria vector.

\section{Estrutura da população de Anopheles (Diptera: Culicidae) em áreas com diferentes graus de colonização humana: Cantá - Roraima - Brasil}

\begin{abstract}
RESUMO
Malária continua sendo uma das mais importantes doenças endêmicas da região Amazônica. Esse estudo mostra o impacto da colonização humana sobre a estrutura populacional de Anopheles. Diversidade, abundância, riqueza e distribuição do gênero Anopheles foi observado em duas áreas com diferentes graus de antropização no município do Cantá, Estado de Roraima, Norte do Brasil. A influência das estações seca e chuvosa sobre a população dos mosquitos também foram investigadas. A captura dos mosquitos foi realizada entre 6:00 e 10:00 pm na estação seca (Fevereiro e Novembro) e estação chuvosa (Maio e Agosto) em quatro locais diferentes. Entre as 11 espécies de Anopheles identificadas através das características dos adultos, An. albitarsis s.l. (45.5\%) e An. darlingi (19.2\%) foram as mais abundantes nas áreas mais intensamente antropizadas, enquanto An. triannulatus (19.2\%) foi a espécie mais comum na área menos modificada. As outras espécies encontradas foram An. nuneztovari (10.9\%), An. oswaldoi (2.0\%), An. evansae (1.7\%), An. brasiliensis (0.6\%), An. intermedius (0.3\%), An. mediopunctatus (0.5\%), An. periassui $(0.08 \%)$ e An. argyritarsis $(0.04 \%)$. A mais alta densidade populacional de mosquitos foi observada em Maio e as mais baixas em Fevereiro e Novembro. Esses resultados demonstram a existência de uma alta diversidade de anofelinos na área estudada e que mudanças antrópicas no ambiente e variabilidade climática afetam a densidade populacional desses vetores.
\end{abstract}

PALAVRAS-CHAVE: Anofelinos, Antropização, Ecologia de Anopheles, Variabilidade climática, Vetor da malária.

\footnotetext{
1 Universidade Federal de Pernambuco, Centro Acadêmico de Vitória. Rua do Alto do Reservatório, s/n - Bela Vista - CEP 55608-680. Vitória de Santo Antão - PE - Brazil. Phone: 558135230670 Fax: 5581 3523-3351. e-mail: elainnechristine@hotmail.com

2 Universidade Federal de Pernambuco, Centro de Ciências Biológicas, Departamento de Zoologia. Rua Prof. Nelson Chaves, s/n Cidade Universitária - CEP $50670-420$ Recife -PE - Brazil. Phone: 5581 21268359. e-mail: jrbsouza@ufpe.br; cleide.ufpe@gmail.com

${ }^{3}$ Fundação Oswaldo Cruz, Centro de Pesquisa Aggeu Magalhães. Av. Moraes Rego, 1235, CEP 50670-420. Cidade Universitária, Recife - PE - Brazil. Caixa - Postal: 7472. Phone: 558121012500. e-mail: marruda@cpqam.fiocruz.br.

${ }^{4}$ Fundação Oswaldo Cruz, Escola Nacional de Saúde Pública, Departamento de Ciências Biológicas. Av. Brasil, 4036, sala 703, CEP: 21040-361, Manguinhos, Rio de Janeiro - RJ - Brazil. Phone: 5521 22903893. e-mail: pmags@ensp.fiocruz.br
} 


\section{INTRODUÇÃO}

Malaria is still responsible for millions of cases and many deaths every year (Breman et al, 2004). Although most cases are reported in Africa, the disease is important in Brazil where $99 \%$ of the cases occur in the Amazon basin (Passos \& Fialho, 1998; Silva \& Oliveira, 2002). Recent surveys have shown a significant increase in the region (MS, 2003), especially in the state of Roraima, which presented a 103\% increase in the Annual Parasite Index (IPA) between 1970 and 2000 (FUNASA, 2004). Between 2003-2004, malaria cases have increased by $200 \%$ in the city of Cantá, Roraima (SESAU-RR, 2004).

Studies show that 500,000 new cases occur in the Amazon region every year (Boulos, 1990; Silva \& Oliveira, 2002). One of the most important factors causing this high number of cases is the intensive human migration to the region. The development of agriculture settlement schemes, uncontrolled migration and non-organized exploitation of natural resources (Oliveira-Ferreira et al., 1992; Chaves \& Rodrigues, 2000; Silva-Vasconcelos et al., 2002) has resulted in changes in the ecological niches of anophelines (Boulos, 1990; Guimarães et al., 2004). This has favored the dispersion of vector species to human-made habitats, increasing the transmission of the malaria parasite in the region (Boulos, 1990). The awareness of human settlement and its impact on the ecology of mosquitoes may lead to strategies for controlling the malaria transmission (Barata, 1995; Rebêlo et al, 1997; Guimarães et al, 2004).

Anopheles (Nynorhynchus) darlingi Root 1926 is considered to be the main vector of malaria in forested areas of Brazil (Deane et al, 1988; Oliveira-Ferreira et al, 1990; Tadei \& Thatcher, 2000; Silva et al, 2006), whereas in the coastal region the most important vector is the Anopheles (Nynorhynchus) aquasalis Curry 1932 (Silva et a, 2006). Anopheles (Nynorhynchus) albitarsis, a complex of four species, is described as a secondary vector (Rosa-Freitas et al,. 1990; Consoli \& Lourenço-de-Oliveira, 1994; Póvoa et al, 2006), yet it has been reported as a primary vector in some areas (Arruda et al, 1986; Silva-Vasconcelos et al, 2002; Póvoa et al, 2006).

Although the epidemiological importance of humaninduced changes in forest areas is widely acknowledged, few studies have addressed the population dynamics of anophelines in newly anthropized areas. Scarcity of this information is detrimental to designing efficient malaria control measures in those areas. Therefore in this work, the diversity of anophelines was compared in localities with variation levels of anthropic environmental changes. Influences of rainy and dry seasons in the mosquito population were surveyed. Mosquito-human host interactions were also evaluated in both areas.

\section{MATERIAL AND METHODS}

\section{STUDY SITES}

Mosquito captures were carried out in Cantá city, Roraima State, Northern Brazil (Figure 1), which has 10.826 inhabitants and a territorial area of $7.691 \mathrm{Km}^{2}$ (IBGE, 2006). Cantás population is concentrated in rural areas and its economic activities are associated with agriculture and livestock. Cantá is $100 \mathrm{~m}$ above sea level, presenting an equatorial climate; mostly hot and sub-humid.
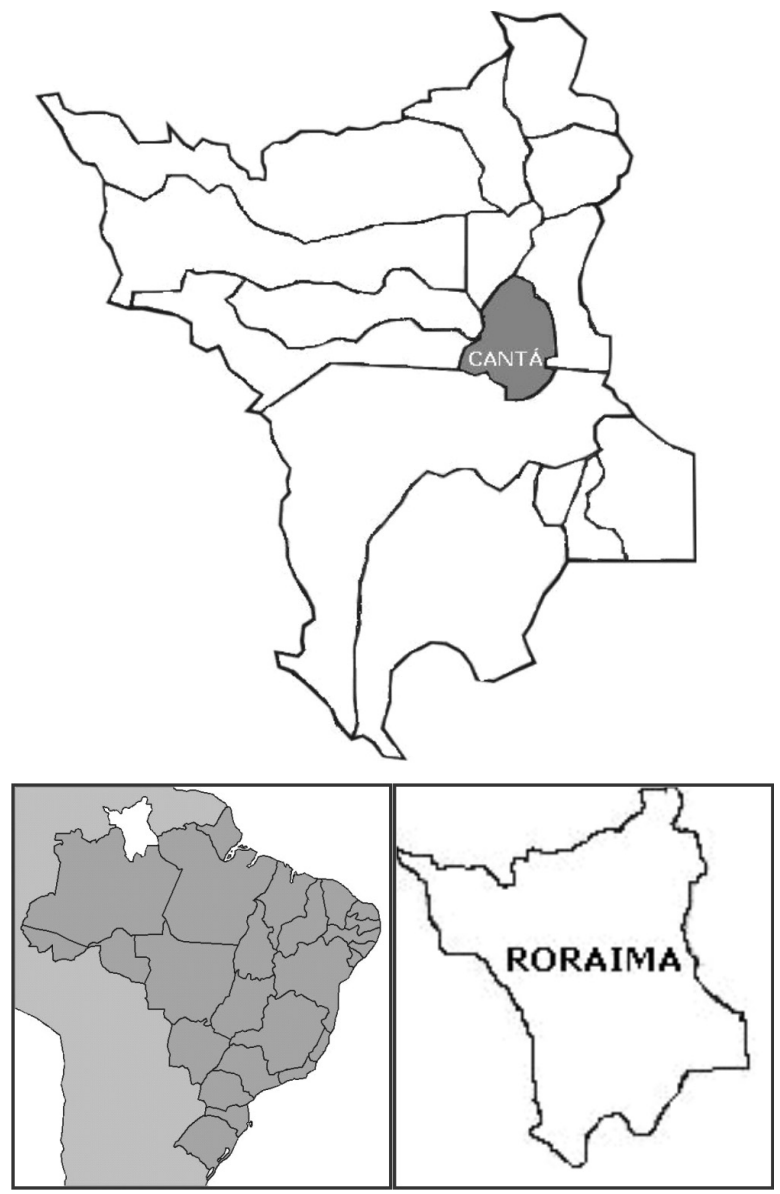

Figure 1 - Location map of the study area; Cantá city, Roraima State, Brazil.

Two Areas (A and B), $14 \mathrm{~km}$ distant from each other, were selected for the anophelines' capture. These areas comprise fragments of the tropical rain forest differing from most of region due to their anthropogenic changes.

Area A was located on the city's primary dirt road (N $02^{\circ} 20^{\prime} 00^{\prime \prime}$; W $\left.060^{\circ} 38^{\prime} 07.6^{\prime \prime}\right)$, having characteristics of a farm intensively changed by human activity. It has three houses, a six bedroom dorm-type building, three small man-made lakes, 
plantations and livestock (cattle, pigs and fowl). It undergoes an intermittent flow of people, especially on weekends and during the soybean harvest.

Area $\mathrm{B}$ is located on the city's secondary dirt road beside a natural lake (vicinal VIII - N 02 $15^{\prime} 32.9^{\prime \prime}$; W 060³3'59.1”). Its vegetation is better conserved than area $\mathrm{A}$. It has a small wooden house, a small man-made lake and a barn for cattle.

Mosquito captures were carried out during three consecutive days in both areas (four sites in each one). A gradual stratification was preformed in both areas from the main house to the forest, for identifying the human settlement impact on the Anopholes population. The border of the forest (site 4) was around $1,500 \mathrm{~m}$ (Area A) and $1,000 \mathrm{~m}$ (Area B) from the house. Site 2 was situated at a distance of around $200 \mathrm{~m}$ from the house and site 3 was between the two former sites. Site 1 was situated around $10 \mathrm{~m}$ from the house.

In 2004, collections were performed in February and November (dry season) and in May and August (rainy season).

Mosquitoes' captures were carried out from 6:00 to 10:00 $\mathrm{pm}$ as they landed on human bait. Previous surveys and the specific literature have shown that this was the time when most of anopheline mosquito bites were reported (Consoli \& Lourenço-de-Oliveira, 1994; Guimarães et al., 2000; Forattini, 2002). Eight entomologist technicians from FUNASA-RR worked simultaneously in the two areas (A and B), under the same environmental conditions (temperature; wind; humidity and light).

Specimens were captured by aspiration and kept in individual vials labeled as for the specific site and hour of sampling. Specimens were killed with ether and the taxonomic identification was performed according to the keys of Gorham et al (1967), Consoli \& Lourenço-de-Oliveira (1994) and Forattini (2002). Specimens belong to the same species were stored in the lab in vials containing silica-gel.

Abiotic factors were hourly measured during the three days of capture. The average maximum and minimum values during this study were: $28 \pm 0.5^{\circ} \mathrm{C}$ for tempetature and $69.7 \pm$ $2.7 \%$ for relative humidity. These values were recorded using a thermohygrometer. Average monthly levels of precipitation were $136 \pm 40.7 \mathrm{~mm}$ (Relatório de Climatologia Aeronáutico, 2000-2003). Sampling during full moon was avoided, since luminosity affects mosquito behavior (Lourenço-de-Oliveira et al, 1985; Murilo et al, 1988). Samplings were usually performed at new moon or half moon.

The Shannon-Wiener diversity index was used to compare the areas. Where $\mathrm{pi}=$ the proportion of mosquitoes species in the sites of the studied areas.
The Analysis of Variance (ANOVA) was used to compare both areas, and the Tukey HSD was used as Post-hoc test.

\section{RESULTS}

Eleven species of anophelines were collected from a total of 2,298 mosquitoes obtained in at all sites between February and November, 2004 (Table 1).

Of this collection, $55.5 \%$ were from area A (anthropized), and $44.5 \%$ from area B. Eleven species were registered in Area A and eight in Area B. Nevertheless, the daily richness and diversity $\left(\mathrm{H}^{\prime}\right)$ were significantly higher in Area $\mathrm{B}$ compared to $A\left(F_{(1,94)}=4.017, p=0.048\right.$ and $F_{(1,94)}=10.433, p=0.002$ respectively).

During the daily richness analysis among sites in both areas, no differences were observed in Area A. However, in Area $\mathrm{B}$, richness was significantly lower at site 1 compared to sites 2 and $3\left(\mathrm{~F}_{(3,44)}=7.877, \mathrm{p}<0.001\right)$ (Figure 2). The mean densities showed different tendencies between areas $\mathrm{A}$ and $B$. A gradual increase in the number of mosquitoes collected was registered from site 1 to 4 in Area B. The opposite was observed in area $\mathrm{A}$, where the density declined towards site 4 (Tabela 1).

Anopheles albitarsis s.l. (45.5\%) was the most abundant species, followed by An. darlingi (19.2\%), An. triannulatus (19.2\%), and An. nuneztovari (10.4\%). These species totaled $94 \%$ of all captured mosquitoes (Table 1). An. Albitarsis s.l. and An. darlingi presented higher abundance in area $\mathrm{A}, \mathrm{F}_{(1 .}$ 94) $=4.132, \mathrm{p}=0.045$ and $\mathrm{F}_{(1,94)}=4.947, \mathrm{p}=0.029$, respectively. The opposite phenomenon was observed for An. Triannulatus, which was four times more frequent in the less modified area, $F_{(1,94)}=9.103, p=0.003$. No density differences were observed among the Areas for other sampled anophelines (Figure 3).

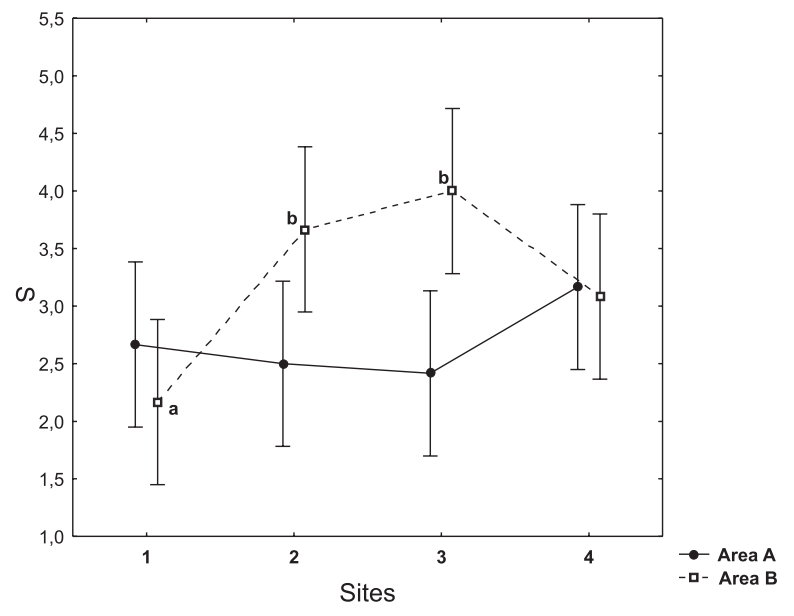

Figure 2 - Anophelines' Richness $(S)$ at the sites of both Areas; $A=$ More anthropized, $B=$ Less anthropized. Cantá city, Roraima State, Brazil. Vertical bars denote 0.95 confidence intervals. 
Table 1 - Total number of anophelines captured at the sampling sites, in the areas A and B, Cantá city, Roraima State, Brazil. A= More Anthropized and B= Less Anthropized.

\begin{tabular}{|c|c|c|c|c|c|c|c|c|c|c|}
\hline \multirow{2}{*}{ Species } & \multicolumn{2}{|c|}{ Site 1} & \multicolumn{2}{|c|}{ Site 2} & \multicolumn{2}{|c|}{ Site 3} & \multicolumn{2}{|c|}{ Site 4} & \multirow[t]{2}{*}{ Total } & \multirow[t]{2}{*}{$\%$} \\
\hline & A & B & A & B & A & B & A & B & & \\
\hline Anopheles albitarsis & 196 & 28 & 183 & 107 & 324 & 204 & 02 & 01 & 1045 & 45.5 \\
\hline An.triannulatus & 0 & 35 & 05 & 64 & 0 & 46 & 81 & 211 & 442 & 19.2 \\
\hline An.darlingi & 162 & 31 & 48 & 47 & 64 & 65 & 14 & 10 & 441 & 19.2 \\
\hline An.nuneztovari & 08 & 16 & 20 & 27 & 16 & 37 & 80 & 46 & 250 & 10.9 \\
\hline An.oswaldoi & 0 & 0 & 0 & 02 & 0 & 02 & 19 & 24 & 47 & 2.0 \\
\hline An.evansae & 02 & 0 & 03 & 02 & 01 & 13 & 18 & 0 & 39 & 1.7 \\
\hline An. brasiliensis & 0 & 0 & 08 & 01 & 0 & 05 & 0 & 0 & 14 & 0.6 \\
\hline An. mediopunctatus & 0 & 0 & 0 & 0 & 0 & 0 & 11 & 0 & 11 & 0.5 \\
\hline An. intermedium & 0 & 0 & 0 & 0 & 0 & 0 & 02 & 04 & 06 & 0.3 \\
\hline An. periassui & 0 & 0 & 01 & 0 & 01 & 0 & 0 & 0 & 02 & 0.08 \\
\hline An. argyritarsis & 0 & 0 & 0 & 0 & 0 & 0 & 1 & 0 & 01 & 0.04 \\
\hline Total & 368 & 110 & 268 & 250 & 406 & 372 & 228 & 296 & 2298 & 100 \\
\hline
\end{tabular}

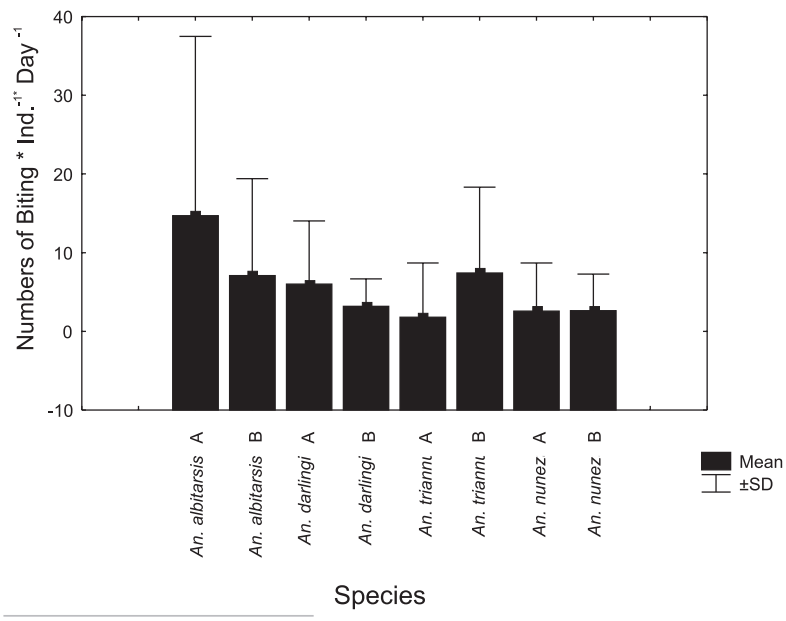

Figure 3 - Dominant anopheline species sampled in each quarter month, from February to November, 2004 in the Areas A and B; Cantá city, Roraima State, Brazil.

An. albitarsis s.l. was significantly more abundant at site 3 and very rare at site 4 of both areas $\left(\mathrm{F}_{(3,92)}=6.599, \mathrm{p}<0.001\right)$ (Table 1). An. darlingi, the primary malaria vector in the Amazon region, was observed at all sites. Higher densities were observed at site 1 and few individuals were captured at site 4 $\left(\mathrm{F}_{(3,92)}=5.980, \mathrm{p}<0.001\right)$ (Table 1$)$. An. triannulatus was found at two sites (2 and 4 ) in area $A$ and at all four sites in B with significantly higher densities at site 4 than in any other site $\left(\mathrm{F}_{(3,92)}=8.434, \mathrm{p}<0.001\right)$ (Table 1). An. Oswaldo $i$ was captured only at site 4 of Area $A$, and at 2, 3 and 4 sites of area $B$, with a preference for site $4\left(\mathrm{~F}_{(3,92)}=4.636, \mathrm{p}=0.005\right)$. An. nuneztovari presented significantly higher density at site 4 than in other sites $\left(\mathrm{F}_{(3,92)}=2.953, \mathrm{p}=0.037\right)$ (Table 1$)$.

February presented a significant lower richness in relation to other months in Area $A\left(F_{(3,44)}=4.666, p=0.006\right)$. The population density of anopheline also varied according to the seasons in area $\mathrm{A}$, with significantly higher density in the rainy season $\left(\mathrm{F}_{(1,46)}=6.955, \mathrm{p}=0.011\right)$ (Figure 4).

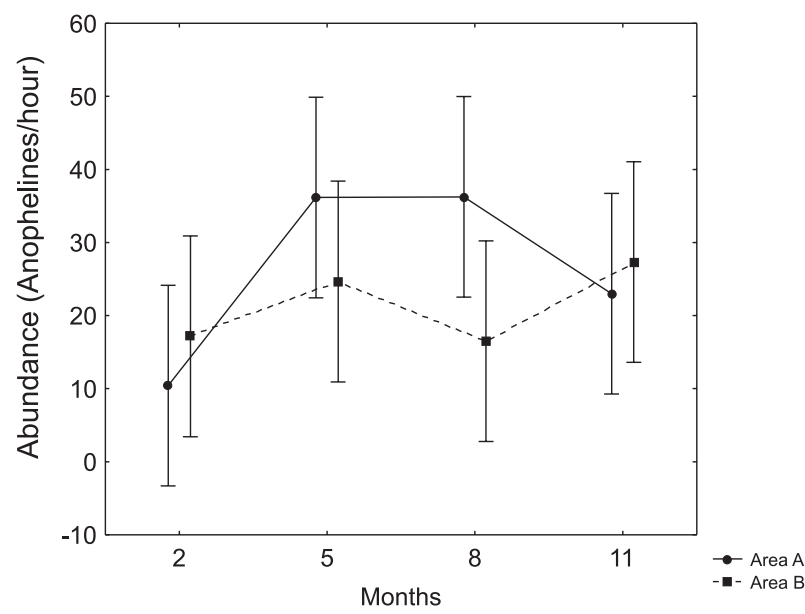

Figure 4 - Anophelines abundance in two areas throughout the months: Cantá city, Roraima State, Brazil. Vertical bars denote 0.95 confidence intervals. 


\section{DISCUSSION}

The significant lower differences of richness and diversity observed in area A, show that anthropic changes induce a higher abundance of endophilic species of Anopheles in the environment. This is reinforced by the dominance of $A n$. albitarsis s.l. and An. darlingi in the anthropized area. These results are in agreement with those observed by Juri et al (2005) who observed a higher diversity of Anophelines in preserved areas in Salta Forest, Argentina. Similarly, Montes (2005) observed a higher dominance and lower diversity of Culicidae species in anthropized areas of the Brazilian Atlantic Forests.

The significantly high diversity at site 3 of area B may be related to the concept that moderate impacts of human settlement increase species diversity. This concept is supported by the "intermediate disturbance hypothesis" proposed by Connell (1978) which suggests that species diversity should be highest at moderate levels of disturbance. This fact can be observed in the figure 2 which shows a high abundance at sites 2 and 3 in area B.

The most efficient malaria vector in the Americas, $A n$. darling (Rozendaal, 1990; Rubio-Pallis, 1995), was the second most common species captured in both areas. It has been considered as the primary vector of this disease in Brazil (Deane, 1986). Silva et al. (2006) emphasize the implication of $A n$. darlingi as a competent vector. High degree of endophyly of $A n$. darlingi has been demonstrated in several papers (Forattini, 1987; Roberts et al., 2002; Silva et al., 2006). In this study, this species was present in low densities in the forest (site 4). It was observed almost exclusively at the modified sites, especially around the house (site 1), a fact which confirms its high degree of association with human dwellings (Oliveira-Ferreira et al., 1992; Lourenço-de-Oliveira \& Luz, 1996; Souza-Santos, 2002; Guimarães et al., 2004; Silva et al, 2006).

Another important species of anopheline, with regard to malaria epidemiology in the Northern Brazil, is the $A n$. albitarsis s.l.. It was the most common species collected in this study and presented the highest densities in the most anthropic area, corroborating the results obtained in Boa Vista, Roraima State, by Silva-Vasconcelos et a.l (2002) and Póvoa et al. (2006). Studies carried out by Tubaki et al. (2004) also showed an adaptation of $A n$. albitarsis s.l. to a newly anthropized area, after a dam construction. The anthropophilic behavior of this species in our study may be observed by the fact that An. albitarsis s.l. was hardly found at the forest site in both areas (Table 1). This species is considered the potential malaria vector in several areas of the country (Arruda et al., 1986; Tadei et al., 1988; Klein et al., 1991; Póvoa et al., 2001).

The predominance of $A n$. albitarsis s.l. associated with the high degree of infection by Plasmodium sp. in Boa Vista,
Roraima, has led several authors to incriminate this species and the $A n$. darlingi as primary vectors of malaria transmission in this part of the country (Silva-Vasconcelos et al., 2002; Póvoa et al., 2006; Barros \& Honório, 2007). Nevertheless, it is important to consider that the Plasmodium infection rate in An. darlingi is twice as high when compared to those observed in the $A n$. albitarsis s.l. Therefore, simultaneous occurrence of these two species in any given locality may have epidemiological relevance, due to the probability of development malaria outbreaks (Deane, 1986; Teodoro et al., 1994; Tadei \& Thatcher, 2000; Póvoa et al., 2006).

In area $\mathrm{B}, A n$. triannulatus and $A n$. oswaldoi colonized different types of sites, although both have shown preference for the forest. Some authors believe that they are mainly associated with wild environments (Lourenço-de-Oliveira et al., 1989; Lourenço-de-Oliveira, 1993; Consoli \& Lourençode-Oliveira, 1994; Lourenço-de-Oliveira \& Luz, 1996). Such observations point to the low degree of anthropophilic activity of those mosquitoes. Similar findings have been reported by Branquinho et al. (1993); Oliveira-Pereira \& Rebelo (2000); Brown et al. (2001) and Póvoa et al. (2001). These authors observed low frequency of these species close to and inside human habitations. The absence of An. triannulatus in areas with environmental changes may be an indication of its potential as a bioindicator of human impact.

Another species predominat in the forest is An. nuneztovari which, however, did not show a clear habitat preference in area A. An. nuneztovari presents exophilic habitats (Tadei \& Correia, 1982; Olano et al., 1997) and has been observed in low densities close to and inside houses (Souza-Santos, 2002); it was predominantly observed inside the forest (Lourenço-deOliveira \& Luz, 1996). These results corroborate with those from this investigation, which showed a lower incidence of this anopheline close to houses (site 1).

Rubio-Palis et al. (1992) collected 47,704 An. nuneztovari in approximately 2 years $(74.8 \%$ of the sample) inside and outside a house in Venezuela and some were infected with P. vivax, detected by the ELISA technique. Moreno et al. (2004) reported An. nuneztovari (citotype B), for the first time, in southeastern Venezuela. They stress the possibility of this species as a primary transmitter of malaria in the region, since this same citotype is the main vector in Colombia and southeastern Venezuela. In Brazil, An. Nuneztovari was found infected with the malaria parasite in the north (Arruda et al., 1986; Póvoa et al., 2001; Silva-Vasconcelos et al., 2002). However, in the urban areas in Roraima, studies have shown low density in the population (Silva-Vasconcelos, 2002; Póvoa et al., 2006) as well as low number of infectious $A n$. nuneztovari (Silva-Vasconcelos, 2002).

Although An. evansae was collected at all surveyed points, it was very rare at site 1 and presented higher densities at sites 3 
and 4, though not significantly different. Low densities of this species were also observed inside houses and in peridomiciliary areas by Oliveira-Pereira $\&$ Rebelo (2000), in the northeastern region of Brazil, and also by Guimarães et al. $(1997,2004)$, in the central-western and southern parts of the country.

Several studies have shown that climatic factors affect the population dynamics of anopheline mosquitoes (Póvoa et al., 2001; Silva-Vasconcelos et al., 2002; Marquetti et al., 1992; Xavier \& Rebêlo, 1999; Moreno et al., 2002). The Roraima State presents two climatic seasons: rainy period (May to September) and dry period (October to April) (Chaves \& Rodrigues, 2000). In the present study the lowest density of anophelines was observed in February (dry period), which presented a significant lower richness in relation to August and November in Area A. In February, most breeding sites were dry, a fact which may be responsible for the significant decrease in mosquito populations. Silva-Vasconcelos et al. (2002) associated the dry season to a decrease in anopheline biting rates. Yet, other studies showed higher mosquito densities at the onset of the dry season (Póvoa et al., 2001) and also an increase in malaria transmission in this period (Charlwood et al., 2000; Chaves \& Rodrigues, 2000). Gurgel (2003) in a spatial-temporal analysis of malaria in Roraima suggested that the increase of malaria cases in the beginning of the dry season was related to standing water in several places. At this time, there is also an increase in the flux of people to areas formerly inundated, thus facilitating contact with mosquitoes.

A regular seasonal pattern of mosquito occurrence was not detected in Area B. A similar fact was observed by Guimarães et al., (1997) studying anophelines in Southern Brazil. Their study detected no influence of the rainy season on mosquito densities and observed that breeding sites did not change during the year, regardless of the rainfall regime. The present study observed the same results. This may also be the phenomenon underlying the observed pattern of low population fluctuations of anophelines in area B, where most breeding sites were permanent.

The highest densities of anophelines were recorded during the rainy season, in captures preformed from May to August, which corresponds to the period with higher abundance of breeding sites created by rain. Significant higher densities were observed in area A in those months. Zimmerman (1992) reported that the seasonal increase in anophelines is regulated by the abundance of breeding sites being it directly related to the rainfall. Several studies reported the same phenomenon, with highest densities of anophelines being observed during the rainy season (Marquetti et al., 1992; Xavier \& Rebêlo, 1999; Moreno et al., 2002, Barros \& Honório, 2007).

Human activity favors an increase in temporary breeding sites and has possibly contributed to the increase observed in anopheline populations in area $\mathrm{A}$. The relation between the breeding of anophelines and the presence of larval habitats created by humans has been reported by other authors. In Africa, Fillinger et al. (2004) observed that from $70 \%$ of all aquatic habitats found in a man-made area, 67\% were colonized by Anopheles larvae, especially that of $A n$. gambiae.

Data obtained in the present work indicate that ecological changes followed by human occupation in the Brazilian Amazon should be considered. This study showed that changes in the environment affect the population dynamics of Anopheles, thus possibly contributing to the increase of malaria transmission. The high degree of sinanthropism of An. darlingi and An. albitarsis s.l., species, considered as important in the epidemiology of malaria in the region, point to the necessity of monitoring these species in both preserved and modified environments. This will probably generate important information on the control of endemic malaria in the region.

\section{ACKNOWLEDGEMENTS}

We are grateful to the technicians of the Fundação Nacional de Saúde, Roraima State, for support during field collection and the identification of specimens.

\section{LITERATURE CITED}

Arruda, M.E.; Carvalho, M.B.; Nussenzweig, R.S.; Maracic, M. Ferreira, W.; Cochrane, A.H. 1986. Potential vectors of malaria and their different susceptibility to Plasmodium falciparum and Plasmodium vivax in northern Brazil identified by immunoassay. Amer. J. Trop. Med. Hyg., 35: 873-881.

Barata, R.C.B. 1995. Malária no Brasil: panorama epidemiológico na última década. Cad. Saúde Públ., 11: 128-136.

Barros, F.S.M.; Honório, N.A. 2007. Man biting rate seasonal variation of malaria vectors in Roraima, Brazil. Mem. Inst. Oswaldo Cruz, 102(3): 299-302.

Boulos, M. 1990. Epidemiologia, patogenia e métodos de controle da malaria humana. Ciência e Cultura, 42 (8): 570-574.

Breman, J.G.; Alilio, M.S.; Mills, A. 2004. Conquering the intolerable burden of malaria: what's new, what's needed: a summary. Amer. J. Trop. Med. Hyg., 71 (Suppl 2): 1-15.

Branquinho, M.S.; Lagos, C.B.T.; Rocha, R.M.; Natal, D.; Barata, J.M.; Nardin, E.; Nussenzwieg, R.S.; Kloetzel, J.K. 1993. Anophelines in the state of Acre, Brazil, infected with Plasmodium falciparum, P. vivax, the variant $P$. vivax VK247 and P. malariae. Trans. R. Soc. Trop. Med. Hyg., 87: 391-394.

Brown, E.; Villegas, C.; Araujo, R. 2001. Abundancia y diversidad de la fauna anofelina en áreas vulnerables a la transmisión malárica del estado Trujillo, Venezuela. Bol. Malar. San. Amb. XLI (1-2): 110.

Charlwood, J.D.; Vij, R.; Billingsley, P.F. 2000. Dry season refugia of malaria-transmitting mosquitoes in a dry savannah zone of east Africa. Amer. J. Trop. Med. Hyg., 62: 726-732. 
Chaves, S.S.; Rodrigues, L.C. 2000. An initial examination of the epidemology of malaria in the state or Roraima, in the Brazilian Amazon basin. Rev. Inst. Med. Trop. São Paulo, 42: 269-275.

Connell, J.H. 1978. Diversity in tropical rain forest and coral reefs. Science. 199: 1302-1310.

Consoli, R.G.B.; Lourenço-de-Oliveira, R. 1994. Principais Mosquitos de Importancia Sanitária. Rio de Janeiro, Editora Fiocruz. 225Pp.

Deane, L.M. 1986. Malaria vectors in Brazil. Mem. Inst. Oswaldo Cruz, 81(Suppl. II): 5-14.

Deane, L.M.; Ribeiro, C.D.; Lourenço-de- Oliveira, R.; OliveiraFerreira, J.; Guimarães, A.E. 1988. Study on the natural history of malaria in áreas of the Rondônia :State, Brazil, and problems related to its control. Rev. Inst. Med. Trop. São Paulo, 30: 153156

Fillinger, U.; Sonye, G.; Killeen, G.F.; Knols, B.J.; Becker, N. 2004. The pratical importance of permanent and semipermanent habitat for controlling aquatic stage of Anopheles gambiae sensu lato mosquitoes: operations from a rural town in western Kenya. Trop. Med. Intern. Health, 9: 1274-1287.

Forattini, O.P. 1987. Comportamento exófilo de Anopheles darlingi Root, em região meridional do Brasil. Rev. Saúde Públ.; 21: 291-304.

Forattini, O.P. 2002. Anophelinae. Culicidologia Médica, vol. 2. São Paulo, Editora da Universidade de São Paulo, 864pp.

FUNASA (Fundação Nacional de Saúde). 2004. Tabela 18 Distribuição dos casos de malária Roraima 1962 - 2002. Estatistica/ FNS/RR/SISMAL/Coordenação de Epidemiologia/ SESAU. Disponível em: https://sis.funasa.gov.br. Acesso: $12 / 2004$.

Gorham, J.R., C.J. Stojanovich, and H.G. Scout. 1967. Clave ilustrada para los mosquitos anofelinos de sudamerica oriental. Bureau of Disease Prevention and Environmental Control, Training Program. Atlanta, Georgia. 64pp.

Guimarães, A.E.; Mello, R.P.; Lopes, C.M.; Alencar, J.; Gentile, C. 1997. Prevalência de Anofelinos (Diptera: Culicidae) no crepúsculo vespertino em áreas da Usina Hidrelética de Itaipu, no município de Guairá, Estado do Paraná, Brasil. Mem. Inst. Oswaldo Cruz, 92: 745-754.

Guimarães, A.E.; Gentile, C.; Lopes, C.M.; Mello, R.P. 2000. Ecology of Mosquitos (Diptera: Culicidae) in Areas of Serra do Mar Parque, State of São Paulo, Brasil. II - Habitat Distribution. Mem. Inst. Oswaldo Cruz, 95: 18-25.

Guimarães, A.E.; Gentile, C.; Alencar, J.; LopesC.M.; Mello, R.P. 2004. Ecology of anopheline (Diptera, Culicidae), malaria vectors around the Serra da Mesa Reservoir, state of Goiás, Brazil. 1 Frequency and climatic factors. Cad. Saúde Públ., 20: 291-302.

Gurgel, H.C., 2003. A utilização das geotecnologias em estudos epidemiológicos: O exemplo da relação entre a malária e o NDVI em Roraima. Anais XI SBSR, Belo Horizonte, Brasil, 05-10 abril 2003, INPE: 1303-1310.

IBGE. 2006. Instituto Brasileiro de Geografia e Estatística. Disponível em: www.ibge.gov.br. Acesso: 05/2007.
Juri, M.J.D.; Zaidenberg, M.; Almirón, W. 2005. Distribución espacial de Anopheles pseudopunctipennis en las Yungas de Salta, Argentina. Rev. Saúde Públ., 39(4): 565-570.

Klein, T.A.; Lima, J.B.P.; Tang, A.T. 1991. Biting behavior of Anopheles mosquitoes im Costa Marques, Rondônia, Brazil. Rev. Soc. Bras. Med. Trop., 24: 13-20.

Lourenço-de-Oliveira, R.; Silva, T.F.; Heyden, R. 1985. Alguns aspectos da ecologia dos mosquitos (Diptera: Culicidae) de uma área de planície (Granjas Calábria), em Jacarepaguá, Rio de Janeiro. II. Freqüência mensal e no ciclo lunar. Memórias do Instituto Oswaldo Cruz, 80(2): 123-133.

Lourenço-de-Oliveira, R.; Guimarães, A.E.; Arlé, M.; Silva, T.F.; Mottaz, M.G.; Deane, L.M. 1989. Anopheline species, some of their habits and relation to malaria in edemic areas of Rondônia Satate, Amazon Region of Brazil. Mem. Inst. Oswaldo Cruz., 84: 501-514.

Lourenço-de-Oliveira, R. 1993. Um estudo sobre a malária simiana na Amazônia e a possibilidade de veiculação da infecção ao homem. Tese de Doutorado, Universidade Federal do Rio de Janeiro, Rio de Janeiro, Brazil. 217pp.

Lourenço-de-Oliveira, R.; Luz, S.L.B. 1996. Simian malaria at two sites in the Brasilian Amazon - II. Vertical distribution and frequency of anopheline species inside and outside the forest. Mem. Inst. Oswaldo Cruz., 91: 687-694.

Marquetti, M.C.; Navarro, A.; Bisset, J.; Garcia, F.A. 1992. Comparison of three catching methods for collecting Anopheline mosquitoes. Mem. Inst. Oswaldo Cruz, 87: 457-458.

MS - Ministério da Saúde 2003. Disponível em: www. ministeriodasaude.gov.br. Acesso em: 12/2004.

Montes, J. 2005. Fauna de Culicidae da Serra da Cantareira, São Paulo, Brasil. Rev. Saúde Públ., 39(4): 578-584.

Moreno, J.; Rubio-Palis, Y.; Pérez, E.; Sánchez, V.; Paez, E. 2002. Evaluación de três métodos de captura de anofelinos em um área endêmica de malaria del estado Bolívar, Venezuela. Entomotrop., 17: 157-165.

Moreno, J.; Rubio-Palis, Y.; Sánchez, V.; Mariany, D. 2004. Primer registro de Anopheles (Nyssorhynchus) nuneztovari Gabaldón, 1940 (Diptera: Culicidae) em el estado Bolívar, Venezuela y sus implicationes eco-epidemiológicas. Entomotrop., 19: 55-58.

Murilo, B.C.; Astaiza, R.; Fajardo, P. 1988. Biologia de Anopheles (Kerteszia) neivai H., D. \& K., 1913 (Díptera: Culicidae) en la costa pacifica de Colombia: III medidas de luminosidad y el comportamento de pecadura. Rev. Saúde Públ., 22(2): 109112.

Olano, V.; Carrasquilla, G.; Méndez, F. 1997. Transmisión de la malaria urbana em Buenaventura, Colômbia: aspectos entomológicos. Rev. Panam. Salud Públ., 1: 1-11.

Oliveira-Ferreira, J.; Lourenço-de-Oliveira, R.; Teva, A.; Deane, L.M; Daniel-Ribeiro, C.T. 1990. Natural malaria infections in anophelines in Rondônia State, Brasilian Amazon. Amer. J. Trop. Med. Hyg., 43: 6-10.

Oliveira-Ferreira, J.; Lourenço-de-Oliveira, R.; Deane, L.M.; DanielRibeiro, C.T. 1992. Feeding preference of Anopheles darlingi in 
malaria endemic areas of Rondônia state - northwestern Brazil. Mem. Inst. Oswaldo Cruz, 87: 601-602.

Oliveira-Pereira, Y.N.; Rebelo, J.M.M. 2000. Espécies de Anopheles no município de Pinheiros (Maranhão), área endêmica de malária. Rev. Soc. Bras. Med. Trop. 33: 443-450.

Passos, A.D.C.; Fialho, R.R. 1998. Malária: Aspectos epidemiológicos e de controle. Rev. Soc. Bras. Med. Trop., 31(Supl. II): 93-105.

Póvoa. M.M.; Wirtz, R.A.; Lacerda, R.N.L.; Miles, M.A.; Warhurst, D. 2001. Malaria vectors in the municipality of Serra do Navio, State on Amapá, Amazon Region, Brazil. Mem. Inst. Oswaldo Cruz. 96: 179-184.

Póvoa, M.M.; Souza, R. T. L.; Lacerda, R. N. L.; Rosa, E.S.; Galiza, D.; Souza, J. R.; Wirtz, R.A.; Schlichting, C.D.; Conn, J.E. 2006. The importance of Anopheles albitarsis and An.darlingi in human malaria transmission in Boa Vista, state of Roraima, Brazil. Mem. Inst. Oswaldo Cruz. 101(2): 163-168.

Rebêlo, J.M.M.; Silva, A.R.; Ferreira, L.A.; Vieira, J.A. 1997. Anopheles (Culicidae, Anophelinae) e a malária em Buriticupu - Santa Luzia, pré-amazônia maranhense. Rev. Soc. Bras. Med. Trop., 30(2): 107-111.

Relatório de Climatologia Aeronáutico. 2000-2003. Serviço Regional de Proteção ao Vôo de Boa Vista - Força Aérea Brasileira - RR. Dados não publicados.

Roberts, D.R.; Manguin, S.; Rejmankova, E.; Andre, R.; Harbach, R.E.; Vanzine, E.; Hakre, S.; Polanco, J. 2002. Spatial distribuition of adult Anopheles darlingi and Anopheles albimanus in relation to riparian in Belize, Central America. J. Vect. Ecol., 21-30

Rosa-Freire, M.G.; Deane, L.M.; Momen, H. 1990. A morphological, behavioural and isoenzymatic study in Anopheles albitarsis from 10 populations. Mem. Inst. Oswaldo Cruz, 275-289.

Rozendaal, J.A., 1990. Observations on the distribution of Anophelines in Suriname with particular reference to the malaria vector Anopheles darlingi. Mem. Inst. Oswaldo Cruz, 85: 221-234.

Rubio-Palis, Y.; Wirtz, R.A.; Curtis, C.F. 1992. Malaria entomological inoculation rates in western Venezuela. Acta Trop., 52: 167174.

Rubio-Palis, Y. 1995. Observaciones sobre el patrón de actividad hematofágica del vector de la malaria Anopheles darlingi en las poblaciones del sur de Venezuela. Bol. de la Direction de Malariologia y Saneamento Ambiental, XXXV(2): 66-70.

SESAU-RR (Secretaria Estadual de Saúde - Roraima). 2004. Informativo da Malária - Secretaria de Saúde do Estado de Roraima - Coordenação Estadual de Malária. 002-2004; Dados não publicados.
Silva, L.H.P.; Oliveira, V.E.G. 2002. O caso brasileiro e o que se pode esperar dos progressos da era genômica. Ciência \& Saúde Coletiva, 7(1): 49-63.

Silva-Vasconcelos, A.M.Y.N.; Kató, E.N.; Mourão, R.T.L.; Souza, Lacerda, R.N.L.; Sibajev, A.; Tsouris, P.; Póvoa, M.M.; Momem, H.; Rosa-Freitas, M.G. 2002. Biting indices, host-seeking activity and natural infection rates of anopheline species in Boa Vista, Roraima, Brazil from 1996 to 1998. Mem. Inst. Oswaldo Cruz 97, 151-161.

Silva, A.N.M.; Santos, C.C.B.; Lacerda, R.N.; Machado, R.L.D.; Povoa, M.M.. 2006. Susceptibility of Anopheles aquasalis and An.darlingi to Plasmodium vivax VK210 and VK247. Mem. Inst. Oswaldo Cruz, 101(5): 547-550.

Souza-Santos, R. 2002. Distribuição sazonal de vetores da malária em Machadinho d'Oeste, Rondônia, Região Amazônica, Brasil. Cad. Saúde Públ., 18: 1813-1818.

Tadei, W.P.; Correia, J.M. 1982. Biologia de anofelinos amazônicos. IV. Observações sobre a atividade de Anopheles nuneztovari Gabaldon (Díptera, Culicidae). Acta Amaz., 12: 71-74.

Tadei, W.P.; Santos, J.M.M.; Costa, W.L.S.; Scarpassa, V.M. 1988. Biologia de anofelinos amazônicos. XII - Ocorrência de espécies de Anopheles, dinâmica de transmissão e controle da málaria na zona urbana de Ariquemes (Rondônia). Rev. Inst. Med. Trop. São Paulo, 30: 221-251.

Tadei, W.P.; Thatcher, B.D. 2000. Malaria vectors in the Brazilian Amazon: Anopheles of the subgenus Nyssorhynchus (1). Rev. Inst. Med. Trop. São Paulo, 42: 87-94.

Teodoro, U.; Guilherme, A.L.F.; Lozovei, A.L.; Filho, V.L.S.; Sampaio, A.A.; Spinosa, R.P.; Ferreira, M.E.M.C.; Barbosa, O.C.; Lima, E.M. 1994. Mosquitos de ambientes peri e extradomiciliares na região sul do Brasil. Rev. Saúde Públ. 28: 107-15.

Tubaki, R.M.; Menezes, R.M.T.R.; Cardoso Junior, P.; Bergo, E.S. 2004. Studies on entomological monitoring: Mosquito species frequency in riverine habitats of the Igarapava dam, southern region, Brazil. Rev. Inst. Med. Trop. S. Paulo, 46(4): 223-229.

Xavier, M.M.S.P.; Rebêlo, J.M.M. 1999. Espécies de Anopheles (Culicidae, Anophelinae) em área endêmica de malária, Maranhão, Brasil. Rev. Saúde Públ., 33: 535-41.

Zimmerman, R.H. 1992. Ecology of malaria vectors in the Americas and future direction. Mem. Inst. Oswaldo Cruz, 87(Suppl. III): 371-383.

Recebido em 31/05/2007

Aceito em 29/12/2007 